\title{
Chitosan for Plant Growth Promotion and Disease Suppression against Anthracnose in Chilli
}

\author{
Jahanara Akter ${ }^{1}$, Rayhanur Jannat ${ }^{1 *}$, Md. Motaher Hossain ${ }^{1}$, Jalal Uddin \\ Ahmed $^{2}$, Md. Tanbir Rubayet ${ }^{1}$
}

\author{
${ }^{1}$ Department of Plant Pathology, Bangabandhu Sheikh Mujibur Rahman Agricultural University, Gazipur-1706, Bangladesh \\ ${ }^{2}$ Department of Crop Botany, Bangabandhu Sheikh Mujibur Rahman Agricultural University, Gazipur-1706, Bangladesh \\ *Corresponding Author: \\ Rayhanur Jannat \\ Assistant Professor, Department of Plant Pathology, Bangabandhu Sheikh Mujibur Rahman Agricultural University, Gazipur- \\ 1706, Bangladesh \\ Email: jannatbau@yahoo.com \\ Tel: +8801718263976; Fax: +88029205333
}

\begin{abstract}
Chitosan is naturally occurring compound potentially used in sustainable agriculture to control plant diseases and enhance growth. An attempt was made to control anthracnose or ripen fruit rot of chilli caused by Colletotrichum capsici in the field under inoculated condition and to increase the growth and yield of chilli by different concentrations of chitosan as seed treatment and foliar application methods. C. capsici isolate "So" was found to be the most virulent against chilli at the time of pathogenicity test. Chitosan at $1 \%$ concentration was found to be most effective against the radial growth of $C$. capsici. Subsequently, seed treatment or foliar spray was done with C. capsici spore suspension $\left(5 \times 10^{6} \mathrm{ml}^{-1}\right)$ and different concentrations of chitosan as per requirement of the treatments. Anthracnose or ripen fruit rot of chilli and postharvest disease incidence (DI) and percent disease index (PDI) were significantly lowest in the treatment $T_{8}$, where seeds were treated with $1 \%$ chitosan combination with foliar spray of chitosan $(0.5 \%)$ in pathogen inoculated condition. On the contrary, anthracnose or ripen fruit rot of chilli and post-harvest DI and PDI were significantly highest in the treatment $T_{1}$, where seeds were treated with $C$. capsici. Germination percentage, growth promoting components, yield and thousand seed weight (TSW) were also highest in treatment $T_{8}$ compared to all other treatments. As a result, the combined use of chitosan as seed treatment (1\%) and foliar spray (0.5\%) appeared to be most effective in controlling anthracnose of chilli and increased yield and yield contributing characters.
\end{abstract}

Keywords- Anthracnose, biological control, chitosan, Colletotrichum capsici, yield.

\section{INTRODUCTION}

Chilli (Capsicum frutescence L.) is an important spice and cash crop that is grown throughout tropical, subtropical and temperate regions. In Bangladesh, 102.06 thousand hectares of cultivable land is under chilli cultivation and the country produced 1.30 lakh tons of chilli in 2015-2016 with an average yield $1.27 \mathrm{t} / \mathrm{ha}$ (Annon., 2017). Diseases are one of the main constrains for the low yield and quality of this crop (Poonpolgun and Kumphai, 2007). Anthracnose or ripen fruit rot of chilli caused by Colletotrichum capsici is one of the most devastating disease of chilli. Anthracnose is mainly a problem on mature fruits, causing severe losses due to both pre-and post-harvest fruit decay (Hadden and Black, 1989). At present diseases are mainly managed by the use of chemicals such as fungicides. The continuous and indiscriminate use of chemicals to manage the crop diseases results in accumulation of harmful chemical residues in the soil, water and grains. The indiscriminate use of chemicals is not only hazardous to living being but also breaks the natural ecological balance by killing the beneficial and antagonistic microorganisms. In addition, over usage of synthetic fungicide has facilitated the development of fungicide resistance among some pathogenic population (Rhouma et al., 2009). Therefore, in the absence of anthracnose resistant cultivars, bio-pesticides, such as chitosan offer a more sustainable approach for the control of diseases in fruits and vegetables (Bautista-Baños et al., 2006; Ali et al., 2010; Maqbool et al., 2010). Chitosan is a linear polysaccharide composed of randomly distributed $-\beta-(1 \rightarrow 4)$-linked Dglucosamine (deacetylated unit). It is made by treating the 
chitin shells of shrimp and other crustaceans with an alkaline substance, like sodium hydroxide. It is considered as a biodegradable and biocompatible material with no toxicity or side effects (Rodriguez-Pedroso et al., 2009). Over the last decade, chitosan polysaccharide has taken on enormous importance in the control of pathogenic microorganisms. The presence of amino groups $\left(-\mathrm{NH}_{2}\right)$ in its chemical structure gives chitosan unique and ideal food conservation and security properties which are exploited through the development of biodegradable edible coatings and films containing natural antimicrobials; it also has elicitor properties that enhance the natural defenses of fruit, vegetables and grains (Bautista-Baños et al., 2016). Vasudevan et al., (2002) suggested that application of chitosan formulation can increase root and shoot length and grain yield. It also increases the growth of nursery-raised plants such as cucumber, pepper and tomato etc. Chitosan coatings can control several fungal diseases in plants such as table grapes (Romanazzi et al., 2006), delay the ripening mechanisms in banana fruits (Maqbool et al., 2010) and induce resistance against many pathogens (Wilson et al.,1994; Benhamou, 1998). It has been hypothesized that the interaction of chitosan with negatively charged molecules on the fungal cell surface causes leakage of proteinaceous compounds (Leuba and Stossel, 1986). It is also believed that the interaction between chitosan and fungi leads to the inhibition of mRNA and protein synthesis (Hadwiger, 1999). However, using chitosan very little is known about disease control and enhancement of growth and yield of chilli in Bangladesh. For that reason, this study was undertaken to select the most effective dose of chitosan in reducing the mycelial growth of $C$. capsici and to evaluate the effect of chitosan in controlling the disease and progress growth and yield of chilli.

\section{MATERIALS AND METHODS}

\subsection{Experimental site and materials}

A field experiment was carried out at Bangabandhu Sheikh Mujibur Rahman Agricultural University, Gazipur, Bangladesh, during the period from March 2016 - August 2017. Seeds sample of chilli variety "BARI Morich 3" was collected from the Bangladesh Agricultural Research Institute (BARI), Gazipur, Bangladesh.

\subsection{Collection, isolation and identification of $\boldsymbol{C}$. capsici}

Three isolates of $C$. capsici were collected from infected region of chilli fruits following standard phytopathological procedures (Dasgupta, 1981; Agostini and Timmer, 1992). Disease samples were collected from the field and carried to the laboratory in polythene bags. The infected plant parts were cut into small pieces $\left(1 \mathrm{~cm}^{2}\right)$ in advance lesion margin where healthy and disease tissues remain together. The cut plant parts and fruit tissues were surface sterilized by $1 \%$ sodium hypochloride $(\mathrm{NaOCl})$ solution for 2-3 minutes then washed three times with sterile deionized water to remove the $\mathrm{NaOCl}$. The cut pieces were then placed onto sterilized agar $(20 \mathrm{ml})$ in glass petridishes and incubated at room temperature $\left(25 \pm 2{ }^{\circ} \mathrm{C}\right)$ until acervuli formation. Conidia produced in acervuli came out in the form of ooze and were placed onto PDA and incubated at room temperature for seven days. The fungal pathogen was identified by observing the morphological feature, acervuli formation, presence or absence of setae, cultural and conidial characters under compound microscope (Barneet and Hunter, 1972).

\subsection{Preparation of spore suspension}

Ten days old culture grown on PDA was flooded with $10 \mathrm{ml}$ of sterilized distilled water. Acervuli and conidia along with mycelial mass were separated from the substratum by scrapping with a narrow edge sterilized glass slide (Sharif and Bhuiyan, 2005). The suspension was sieved through double layer cheese cloth to discard acervuli and mycelial mass. The spore suspension was adjusted to $5 \times 10^{6} \mathrm{ml}^{-1}$ by adding sterilized distilled water and counting under compound microscope using counting slide (haemocytometer). Seeds were submerged in spore suspension with gentle stirring for 5 minutes. The wetted seeds were air dried in a sterile cabinet and prepared for further treatment.

2.4 Pathogenicity test for the selection of virulent isolate of the test pathogen in pot culture

Three isolates of $C$. capsici named as So, Mo and Ba were evaluated for their pathogenicity test in the pot culture experiment under the shade condition. Each earthen pot was filled with $2.0 \mathrm{~kg}$ sterilized soil. Twenty-five pieces of chilli seeds for each pot were inoculated with spore suspension of So, Mo and $\mathrm{Ba}$ isolate of $C$. capsici. Then, the inoculated seeds were sown in each pot and in control pot healthy seeds were sown without inoculation. Disease development was observed regularly and recorded at 10 to 20 days after sowing to estimate the effect of pathogens in causing preemergence and post-emergence seedling mortality. The causal agent of seedling mortality was confirmed after reisolation of the pathogen from un-germinated seeds.

\subsection{Pathogenicity test of the test pathogen on detached chilli fruit}

Pathogenicity test with three selected isolates of the pathogen C. capsici was conducted by inoculating harvested chilli fruit. Each isolate of $C$. capsici was grown on PDA plates separately. Inoculation was made by puncturing the tissue with small sterilized needle and then spore suspension $\left(5 \times 10^{6}\right.$ spore $\mathrm{ml}^{-1}$ ) of C. capsici sprayed over the chilli fruit. After 
inoculation, chilli fruits were kept in a separate transparent polyethylene bag to avoid drying. Inoculated chillies were incubated for four days at room temperature. After four days, percent disease index (PDI) was rated following 0-4 scale, where $0=$ No visible sign or symptoms, $1=1-25 \%, 2=26-50 \%$, $3=51-75 \%$ and $4=76-100 \%$ infection on chilli fruits (Abraham et al., 1996).

\subsection{Collection of chitosan}

Chitosan was collected from Bangladesh Atomic Energy Commission (BAEC), Dhaka, Bangladesh. Chitosan was derived from the shell of quick growing sea shrimp. The solution was extracted from sea shrimp and then it was irradiated with $\gamma$-ray $(20 \mathrm{kD})$ which acts as a plant growth promoter.

\subsection{In-vitro evaluation of chitosan for their inhibitory} effect on the radial growth of $\boldsymbol{C}$. capsici

Several preliminary evaluations of chitosan were done with different concentration of chitosan such as $0.4 \%, 0.6 \%$, $0.8 \%, 1 \%$ and $1.2 \%$ on PDA plate against the $C$. capsici. Plates were individually challenged at the center with equal agar plug ( $5 \mathrm{~mm}$ in diameter) taken from 7 days old culture of the pathogen and incubated at $25^{\circ} \mathrm{C}$. Mean colony diameter was measured when the control plate (without chitosan) reached full growth. The radial growths of $C$. capsici in three replications were recorded separately and there averages were taken. The percent inhibition of the radial growth was calculated as described by Sundaret al., (1995).

$\%$ inhibition over control $=\frac{\mathrm{X}-\mathrm{Y}}{\mathrm{X}} \times 100($ equation 1$)$

Where,

$\mathrm{X}=$ Mycelial growth of pathogen without chitosan (control),

$\mathrm{Y}=$ Mycelial growth of pathogen with chitosan

\subsection{Seed treatment with chitosan and rising of seedlings}

Seeds of chilli were surface sterilized by immersion of $1 \%$ $\mathrm{NaOCl}$. Then seeds were thoroughly rinsed in sterile distilled water and immersed into each of the chitosan solution $\left(\mathrm{p}^{\mathrm{H}}\right.$ 5.5-6.0) at concentrations ranging from 0.6-1\%. After gentle stirring, seeds were submerged for 1 hour. Finally, the wetted seeds were air dried in a sterile cabinet and sown in the tray containing soil that was well prepared through mixing fertilizers and cow dung. Chitosan $(0.5 \%)$ was applied as foliar spray at three times such as 10 days after transplanting, at vegetative stage and fruiting stage.

\subsection{Land preparation and transplanting of seedlings}

Land was prepared with well tilth using a tractor driven disc plough and harrow. After land preparation the whole experimental area was divided into three blocks, representing three replications. The unit plot size was $3.0 \mathrm{~m} \mathrm{X} 2.0 \mathrm{~m}$.
Distance between block to block was $1.0 \mathrm{~m}$ and that plot to plot in a block was $0.50 \mathrm{~m}$. Drains were made surrounding the each unit plots and the excavated soil was used for raising plots $15 \mathrm{~cm}$ high from the general soil surface. Ten different treatments were allotted randomly to each block. Thirty-five days aged apparently healthy chilli seedlings of variety 'BARI Morich 3" was collected from the tray. A total of 12 seedlings were planted in each plot on November 2016. Weeding, irrigation and other intercultural operations were done as and when necessary until the maturity of plants.

\subsection{Treatments of the experiment}

The treatments of the field experiment were as follows:

$\mathrm{T}_{0}=$ Untreated healthy seeds without pathogen (Control 1)

$\mathrm{T}_{1}=$ Seed treated with $C$. capsici (Control 2)

$\mathrm{T}_{2}=$ Seed treated with $C$. capsici $+0.6 \%$ chitosan

$\mathrm{T}_{3}=$ Seed treated with $C$. capsici $+0.8 \%$ chitosan

$\mathrm{T}_{4}=$ Seed treated with $C$. capsici $+1 \%$ chitosan

$\mathrm{T}_{5}=$ Seed treated with $C$. capsici + Foliar spray $(0.5 \%)$ of chitosan

$\mathrm{T}_{6}=\mathrm{T}_{2}+$ Foliar spray $(0.5 \%)$ of chitosan

$\mathrm{T}_{7}=\mathrm{T}_{3}+$ Foliar spray $(0.5 \%)$ of chitosan

$\mathrm{T}_{8}=\mathrm{T}_{4}+$ Foliar spray $(0.5 \%)$ of chitosan

$\mathrm{T}_{9}=$ Seed treated with $C$. capsici $+0.1 \%$ Bavistin $50 \mathrm{WP}$

\subsection{Observation of disease development}

Chilli plants were observed regularly after transplanting of seedlings to record the incidence of post emergence seedling mortality, anthracnose diseases on fruits. The disease incidence was recorded two times at 90 and 120 day after transplanting (DAT). Observations were made by selecting six plants randomly from each plot. Flowerings of chilli plants were started at 40-45 DAT. Plants were produced flowers and fruits continuously up to 3-4 months after transplanting. But all fruits didn't mature and ripe at a time. The ripened fruits were harvested and weighed and it was continued up to 4 months after transplanting. Post-harvest disease incidence and PDI were recorded in the laboratory at 135 days after harvesting (DAH).

\subsection{Data recording and disease assessment}

Data were taken on germination percentage, mortality percentage, root length and shoot length, root fresh weight and shoot fresh weight, root dry weight and shoot dry weight, plant height and number of branch, disease incidence and percent disease index (PDI) and yield. The following formulae were used for calculation (Rahman et al., 2013).

Disease incidence

$$
\begin{aligned}
& =\frac{\text { Number of infected plants }}{\text { Total number of plants assessed }} \\
& \times 100 \text { (equation } 2)
\end{aligned}
$$


Disease index $=$

Summation of all rating of fruits observed

Number of fruits observed $\times$ Maximum rating $\times 100$ (equation 3 )

Percent disease index (PDI) was rated by following 0-4 scale, where $0=$ No visible sign or symptoms, $1=1-25 \%, 2=26-50 \%$, $3=51-75 \%$ and $4=76-100 \%$ infection on chilli fruits.

\subsection{Experimental design and data analysis}

The experiment was laid out in a Randomized Complete Block Design (RCBD) with three replications. Data recorded on various parameters were analyzed statistically using the Statistix 10 statistical computer programme after proper transformation whenever necessary. The means were compared following LSD (Least significance Differences) test (Gomez and Gomez, 1984).

\section{RESULTS}

3.1 Pathogenicity test of $C$. capsici isolates against chilli seedlings in pot culture and detached chilli fruits

The pathogenicity test of the three selected isolates of $C$. capsici against chilli seedlings variety BARI Morich-3 were conducted in pot containing sterilized soil to find out most virulent isolate of the test pathogen. All the isolates of the test pathogen were virulent but variable in causing total seedling mortality of chilli ranged from 28.32-63.00\% (Table 1 and Fig. 1-2). The C. capsici isolate So was appeared to be the most virulent causing the highest $63.00 \%$ total seedling mortality followed by isolate Mo caused $43.00 \%$ mortality. Significantly the lowest $28.32 \%$ total seedling mortality was observed with the isolate $\mathrm{Ba}$. No pre-emergence and postemergence seedling mortality was observed in the untreated control pot. Furthermore, every isolates were sowed pathogenic reaction to the detached chilli fruit (Table 1 and Fig. 3). All the three isolates were able to develop characteristics symptom such as sunken necrotic lesion with concentric ring of acervuli in chilli fruits. Chilli fruit which was inoculated with the isolate So showed highest PDI $(83.33 \%)$. The virulence of the isolates in detached fruits was supported by the virulence of the same isolates in the earlier pot culture.

\subsection{Effect of chitosan on mycelial growth of virulent} isolate of $C$. capsici

The mycelial growth of the test pathogen was significantly reduced with all the five selected concentrations viz., $0.4 \%$, $0.6 \%, 0.8 \%, 1 \%$ and $1.2 \%$ of chitosan as compared to untreated control (Table 2 and Fig. 4). All the five concentrations of chitosan are significantly variable in reducing the mycelial growth of $C$. capsici. Significantly the highest $100.00 \%$ reduction of the mycelial growth of $C$. capsici over the control PDA plate was observed at both $1 \%$ and $1.2 \%$ of chitosan amended with PDA plate followed by the second highest $0.8 \%$ of chitosan with $87.79 \%$ reduction of mycelial growth. Significantly the lowest $28.56 \%$ reduction of the mycelial growth of $C$. capsici was observed at the lowest $0.4 \%$ concentration of chitosan amended with the PDA plate. Based on the in-vitro evaluation $0.6 \%, 0.8 \%$ and $1 \%$ chitosan concentrations were selected for the field trial.

\subsection{Effect of chitosan on germination percentage and post-emergence seedlings mortality}

In addition, to know the effect of chitosan on germination and post-emergence seedling mortality chilli seeds were treated with $0.6 \%, 0.8 \%$ and $1 \%$ of chitosan. For positive control Bavistin (0.1\%) $50 \mathrm{WP}$ was used and there was no treatment in untreated control seeds. These seeds were sown in plastic tray after required treatments and data were recorded up to complete germination. All treatments increased the germination percentage compared to the treatment where seeds treated with $C$. capsici (Table 3). The range of germination percentage was 56.37-92.10\%. Significantly the highest germination percentage $92.10 \%$ was in the treatment where seeds were treated with $C$. capsici and $1 \%$ chitosan and significantly the lowest germination percentage $56.37 \%$ was in the treatment where seeds were treated with $C$. capsici without chitosan or any fungicides such as Bavistin (0.1\%). In case of seedling mortality all treatments reduced post-emergence seedling mortality compared to the treatment where seeds were treated with $C$. capsici (Table 3). Significantly the lowest $7.67 \%$ postemergence seedling mortality was found in the treatment where seeds were treated with $C$. capsici and $1 \%$ chitosan. No statistical difference was found among the treatments where seeds were treated with $0.6 \%$ chitosan, $0.8 \%$ chitosan and $0.1 \%$ Bavistin. This experiment showed that seed treatment with $1 \%$ chitosan was most effective to increase germination and to control post-emergence seedling mortality of chilli.

\subsection{Effect of chitosan and Bavistin on growth of chilli seedlings}

Thirty-five days after sowing growth promoting components such as shoot length, root length, fresh shoot weight, fresh root weight, dry shoot weight and dry root weight were increased in the treatments where seeds were treated with chitosan in pathogen inoculated condition comparison to the treatment where seeds were treated with $C$. capsici (Table 4). Seed treatment with $1 \%$ chitosan showed the highest shoot length $(14.84 \mathrm{~cm})$, root length $(8.09 \mathrm{~cm})$, fresh shoot weight $(0.63 \mathrm{~g})$, fresh root weight $(0.045 \mathrm{~g})$, dry shoot weight $(0.084$ $\mathrm{g})$ and dry root weight $(0.0098 \mathrm{~g})$ in pathogen inoculated condition. The lowest shoot length $(9.48 \mathrm{~cm})$, root length 
$(4.68 \mathrm{~cm})$ and fresh shoot weight $(0.46 \mathrm{~g})$ were recorded in the treatment where seeds were untreated and the lowest fresh root weight $(0.019 \mathrm{~g})$, dry shoot weight $(0.055 \mathrm{~g})$ and dry root weight $(0.0020 \mathrm{~g})$ were recorded in the treatment where seeds were treated with $C$. capsici. In the field, plant height and number of branches were observed at mature stage of chilli plant. All the applications of chitosan as seed treatment or foliar spray increased the plant height and number of branches in comparison to the treatment $T_{1}$ where seeds were treated with $C$. capsici (Table 5). The highest plant height $(58.57 \mathrm{~cm})$ at flowering stage $(45 \mathrm{DAT})$ and $(60.83 \mathrm{~cm})$ at fruiting stage (60 DAT) were recorded in the treatment $\mathrm{T}_{8}$ where seeds were pathogen inoculated condition and treated with $1 \%$ chitosan and foliar spray $(0.5 \%)$ of chitosan. The lowest plant height $(45.52 \mathrm{~cm})$ at flowering stage and $(47.93 \mathrm{~cm})$ at fruiting stage were recorded in the treatment $\mathrm{T}_{1}$ where seeds were treated with $C$. capsici. In the same way, the highest number of branches (17.55) at flowering stage and (21.59) at fruiting stage were recorded in the treatment $\mathrm{T}_{8}$ where seeds were pathogen inoculated condition and treated with $1 \%$ chitosan and foliar spray $(0.5 \%)$ of chitosan. The lowest number of branches (11.30) at flowering stage and (13.18) at fruiting stage were recorded in the treatment $T_{1}$ where seeds were treated with $C$. capsici.

3.5 Effect of chitosan and Bavistin on disease incidence (DI) and percent disease index (PDI)

Disease incidence and percent disease index (PDI) were reduced in the treatments where chitosan or Bavistin were used as seed treating agent or foliar spray of chitosan over pathogen treated plots. Disease incidence and PDI were recorded two times before first and second harvesting of fruits. Significantly the highest DI $(64.67 \%)$ at 90 days after transplanting (DAT) and $(90.33 \%)$ at 120 DAT and PDI (3.34\%) at 90 DAT and (4.96\%) at 120 DAT were recorded in the treatment $\mathrm{T}_{1}$ where seeds were treated with $C$. capsici (Table 6). Significantly the lowest DI (10.08\%) at 90 DAT and $(22.63 \%)$ at 120 DAT and PDI $(0.51 \%)$ at 90 DAT and $(1.29 \%)$ at 120 DAT were recorded in the treatment $\mathrm{T}_{8}$ where seeds were pathogen inoculated condition and treated with $1 \%$ chitosan and foliar spray $(0.5 \%)$ of chitosan.

\subsection{Effect of chitosan and Bavistin on the yield and thousand seed weight (TSW) of chilli}

Results of the present study indicates that by the application of different treatments of chitosan yield and yield contributing components were significantly increased in all the treatments over the treatment $T_{1}$ where seeds were treated with $C$. capsici (Table 7). Significantly the highest yield ( $7.03 \mathrm{t} / \mathrm{ha}$ ) was recorded in the treatment $\mathrm{T}_{8}$ where seeds were treated with $C$. capsici, $1 \%$ chitosan in combination with foliar spray $(0.5 \%)$ of chitosan. Significantly the lowest yield
(2.86 t/ha) was recorded in the treatment $\mathrm{T}_{1}$ where seeds were treated with $C$. capsici. Total three harvests were done at different times as chilli is an indeterminate crop and fruits are not mature and ripen at the same time. Moreover, applications of chitosan significantly increased TSW compare to pathogen inoculated condition. Significantly highest TSW $(5.04 \mathrm{~g})$ was recorded in the treatment $\mathrm{T}_{8}$ where seeds were pathogen inoculated condition and treated with $1 \%$ chitosan and foliar spray $(0.5 \%)$ of chitosan. On the contrary, significantly the lowest TSW (4.08 g) was recorded in the treatment $\mathrm{T}_{1}$ where seeds were treated with $C$. capsici.

3.7 Effect of chitosan and Bavistin on post-harvest disease incidence (DI) and percent disease index (PDI)

Post-harvest disease incidence and PDI were recorded in the laboratory at 135 days after harvesting (DAH). Post-harvest disease incidence and PDI were reduced in those treatments where chitosan or Bavistin were used as seed treating agent or foliar spray $(0.5 \%)$ of chitosan in the field compare to pathogen inoculated condition (Table 8). Significantly the highest post-harvest DI $(32.61 \%)$ and PDI $(0.165 \%)$ were recorded in the treatment $\mathrm{T}_{1}$ where seeds were treated with $C$. capsici. Significantly the lowest post-harvest DI $(8.58 \%)$ and PDI $(0.026 \%)$ were recorded in the treatment $\mathrm{T}_{8}$ where seeds were treated with $1 \%$ chitosan combined with foliar spray of $0.5 \%$ chitosan in pathogen inoculated condition.

\section{DISCUSSION}

The anthracnose or ripen fruit rot of chilli is a seed borne as well as soil borne disease caused by Colletotrichum capsici that occurs every year with intensities and imposes considerable quantitative and qualitative losses of the crop in the field as well as in the storage. This disease is mostly difficult to control as Colletotrichum species naturally produce micro-sclerotia to allow dormancy in the soil during the winter or when subjected to stressful conditions and these micro-sclerotia can survive for many years (Pring et al., 1995 ) and subsequently attack the crop resulting poor yield. In recent times, chitosan has been extensively used to control fungal diseases in many fruits and vegetables. In this study, all the tested concentrations of the chitosan were found effective against $C$. capsici which was a dose dependent manner. The complete reduction of the mycelial growth of $C$. capsici was got at $1 \%$ of chitosan. The result is supported by the reports of Chookhongkga et al., 2013 where chitosan was found to reduce the mycelial growth of Rhizopus sp., C. capsici, C. gloeosporioides and Asperillus niger. Chitosan shows direct toxicity to pathogens, can form physical barriers around the penetration sites of pathogens, preventing them from spreading to healthy tissues and is known to induce reactions locally and systemically that entail signaling 
cascades, and the activation and accumulation of defensesrelated antimicrobial compounds and proteins. It is also reported to induce a decline in malondialdehyde content, alter the relative permeability of the plasma membrane and increase the concentrations of soluble sugars and proline, and of peroxidase and catalase activities. Chitosan is often used in plant disease control as a powerful elicitor rather than a direct antimicrobial or toxic agent (Algam et al., 2010).

We observed highest seedling mortality, disease incidence (DI) and percent disease index (PDI) and lowest seed germination, growth, yield and thousand seed weight (TSW) of chilli in pathogen inoculated condition. Application of chitosan increased seed germination, growth promoting components, yield and TSW and reduced seedling mortality, DI and PDI. The highest post-emergence mortality was found in chilli caused by $C$. capsici. The pre-emergence and postemergence mortality of different vegetable crops including chilli caused by the tested pathogen are also reported by Simi, 2017. Significantly the highest germination percentage and the lowest post-emergence seedling mortality were found in the treatment where seeds were treated with $C$. capsici and $1 \%$ chitosan. The results are supported by Photchanachai et al., 2012 and Nitu et al., 2016 that chitosan increased germination percentage and reduced post-emergence seedling mortality of different crops. Moreover, we have observed highest shoot length, root length, fresh shoot weight, fresh root weight, dry shoot weight and dry root weight in the treatments where seeds were treated with chitosan in pathogen inoculated condition compared to the treatment where seeds were treated with $C$. capsici. The results of the present study supported by the observation of Benhamou et al., 1994, O'Herlihy et al., 2003; Guan et al., 2009 who observed the enhancement of growth promoting components including shoot length, root length etc. of different crops by chitosan. Chitosan has also been extensively utilized as a foliar treatment to control the growth, spread and development of fungal diseases and to increase yield and quality in many crops. Consequently, we found that foliar application of chitosan increased the plant height and number of branches. The highest plant heights and number of branches and the lowest DI and PDI were recorded in the treatment $\mathrm{T}_{8}$ where seeds were treated with $1 \%$ chitosan combination with foliar spray of $0.5 \%$ chitosan in pathogen inoculated condition. These results are supported by Mondal et al., (2013) that foliar application of chitosan increased most of the morphological characters such as plant height, leaf number per plant and growth such as total dry mass per plant, absolute growth rate, relative growth rate with increasing concentration of chitosan in okra. Moreover, Faoro et al., (2008) showed that the use of chitosan applied as a foliar spray on barley reduced locally and systemically the infection by powdery mildew pathogen Blumeria graminis f. sp. hordei. The results of the current study justify the statement of Benhamou et al., (1994); O'Herlihy et al., (2003) and Edirisinghe et al., 2014 that chitosan has been considered as alternate to chemical fungicides to control diseases in different crops. However, significantly highest yield and TSW of chilli were recorded in the treatment $\mathrm{T}_{8}$ and these results are supported by Walker et al., (2004) and Mondal et al., (2013) that chitosan increased yield and yield attributes with increasing concentration of chitosan in different crops. Edirisinghe et al., (2014) and Sivakumar et al., (2016) also examined that chitosan could become a promising substance to control postharvest diseases in different crops. Accordingly, post-harvest DI and PDI were reduced by all the chitosan treatments over the treatment $T_{1}$ and significantly lowest post-harvest DI and PDI were found by combined use of chitosan as seed treatment and foliar spray. Edirisinghe et al., (2014), Berumen-Varela et al., (2015), Romanazzi \& Feliziani (2016) and Sivakumar et al., (2016) reported that chitosan increases phenyl ammonia lyase, chitinase (endo and exochitinases) and $\beta$-1,3-glucanase activities in numerous treated tropical and temperate fruits. They also found that chitosan application induces fruit disease resistance during fungal infection through regulation of reactive oxygen species (ROS) levels, antioxidant enzymes, and the ascorbate-glutathione cycle. The present study revealed that combined use of chitosan as seed treatment and foliar spray could provide excellent protection against anthracnose or ripen fruit rot of chilli, had influenced on growth promoting components, yield, TSW and reduced post-harvest DI and PDI.

\section{CONCLUSION}

The present study showed that seed treatment with $1 \%$ chitosan combined with foliar spray of $0.5 \%$ chitosan was appeared to be excellent in controlling post-emergence seedling mortality, anthracnose or ripen fruit rot of chilli, post-harvest disease incidence (DI) and percent disease index (PDI) with the significant increase of growth, yield and thousand seed weight. Moreover, Chitosan at $1 \%$ concentration completely inhibited the mycelial growth of $C$. capsici in in vitro evaluation. Growers can adopt eco-friendly control measures against anthracnose or ripen fruit rot of chilli through the seed treatment with $1 \%$ chitosan combined with foliar spray of $0.5 \%$ chitosan as an alternative to chemical fungicides. 


\section{ACKNOWLEDGEMENT}

The authors gratefully acknowledge and express sincere thanks to Ministry of National Science and Technology (NST), Government of the People's Republic of Bangladesh for providing NST fellowship during the period of study and Institute of Nuclear Science and Technology (INST), Bangladesh Atomic Energy Commission (BATC) for proving chitosan are greatly appreciated.

\section{REFERENCES}

[1] Abraham, J., Anandaraj, M. Ramana, K.V., and Sarma, Y.R. (1996). A simple method for indexing Phytophthora and nematode infection in black pepper (Piper nigrum L.). Journal of Spices Aromatic Crops. 5: 68-71.

[2] Agostini, J. P., and Timmer, L. W. (1992). Selective isolation procedure for differentiation of two strains of Colletotrichum gloeosporioides from citrus. Plant Disease. 76: 1176-1178.

[3] Algam, S. A. E., Xie, G. L., Li, B., Yu, S. H., Su, T., and Larsen, j. (2010). Effects of Paenibacillus strains and chitosan on plant growth promotion and control of Ralstonia wilt in tomato. Journal of Plant Pathology. 92: 595-602.

[4] Ali, A., Mahmud, T. M. M., Sijam, K., and Siddiqui, Y. (2010). Potential of chitosan coating in delaying the postharvest anthracnose (Colletotrichum gloeosporioides Penz.) of Eksotika II papaya. International Journal of Food Science and Technology. 45: 2134-2140.

[5] Anonymous. (2017). Statistical Year Book of Bangladesh (2015-2016). Bangladesh Statistics Division, Ministry of Planning, Govt. of the People's Republic of Bangladesh. pp. 318-319.

[6] Barneet, H. L., and Hunter, B. B. (1972). Illustrated genera of Imperfect fungi, forth ed., USA: Burges s Publishing Company.

[7] Bautista-Baños, S., Hernandez-Lauzardo, A. N., Velazquez-del Valle, M. G., Hernandez-Lopez, M., Ait, B. E., Bosquez-Molina, E., and Wilson C. L. (2006). Review: chitosan as a potential natural compound to control pre and postharvest diseases of horticultural commodities. Crop Protection. 25: 108-118.

[8] Bautista-Baños, S., Romanazzi, G., and JiménezAparicio, A. (2016). Chitosan in the Preservation of Agricultural Commodities. USA: Academic Press/Elsevier.

[9] Benhamou, N., Kloepper, J. W., and Tuzun, S. (1998). Induction of resistance against Fusarium wilt of tomato by combination of chitosan with an endophytic bacterial strain: ultrastructure and cytochemistry of the host response. Planta. 204: 53-168.

[10] Benhamou, N., Lafontaine, P. J., and Nicole, M. (1994). Seed treatment with chitosan induces systemic resistance to Fusarium crown and root rot in tomato plants. Phytopathology. 84: 1432-1444.

[11] Berumen-Varela, G., Coronado-Partida, L. D., OchoaJimenez, V. A., Chacon-Lopez, M. A., and GutierrezMartinez, P. (2015). Effect of chitosan on the induction of disease resistance against Colletotrichum sp. in mango (Mangifera indica L.) cv. Tommy Atkins. Investigaciony Ciencia. 23(66): 16-21.

[12] Chookhongkga, N., Sopondilok, T., and Photchanachai, S. (2013). Effect of chitosan and chitosan nanoparticles on fungal growth and chilli seed quality. International Conference on Postharvest Pest and Disease Management in Exporting Horticultural Crops-PPDM. 973: 231-237.

[13] Dasgupta, B. (1981). Sporulation and relative virulence among isolates of Colletotrichum capsici causing anthracnose of betel vine. India Phytopathology. 32(4): 169-199.

[14] Edirisinghe, M., Ali, A., Maqbool, M., and Alderson, P. G. (2014). Chitosan controls postharvest anthracnose in bell pepper by activating defense-related enzymes. Journal of Food Science and Technology. 51(12): 4078-4083.

[15] Faoro, F., Maffi, D., Cantu, D., and Iriti, M. (2008). Chemical-induced resistance against powdery mildew in barley: the effects of chitosan and benzothiadiazole. Biocontrol. 53: 387-401.

[16] Gomez, K. A., and Gomez, A. A. (1984). Statistical Procedures for Agricultural Research. Second ed. NY, USA: John, Wiley and Sons.

[17] Guan, Y., Hu, J., Wang, X., and Shao, C. (2009). Seed priming with chitosan improves maize germination and seedling growth in relation to physiological changes under low temperature stress. Journal of Zhejiang University and Science. 10(6): 427-433.

[18] Hadden, J. F., and Black, L. L. (1989). Anthracnose of Pepper Caused by Colletotrichum spp. Proceeding of the International Symposium on Integrated Management Practices: Tomato and Pepper Production in the Tropics. Asian Vegetable Research Development Centre, Taiwan. pp. 189-199.

[19] Hadwiger, L. A. (1999). Host-parasite interactions: elicitation of defense response in plants with chitosan. In: Jolles, P., and Muzzarelli, R. A. A. editors. Chitin and chitinases. Birkhauser Verlag, Basel. pp. 185-200. 
[20] Leuba, J. L., and Stossel, P. (1986). Chitosan and other polyamines: anti-fungal activity and interaction with biological membranes. In: Muzzarelli, R. A. A., Jeuniaux, C., and Gooday, G. W. editors. Chitin in nature and technology. Plenum Press, New York. pp. 215-222.

[21] Maqbool, M., Ali, A., Ramachandran, S., Smith, D. R., and Alderson, P. G. (2010). Control of postharvest anthracnose of banana using a new edible composite coating. Crop Protection. 29: 1136-1141.

[22] Mondal, M. M. A., Malek, M. A., Puteh, A. B., and Ismail, M. R. (2013). Foliar application of chitosan on growth and yield attributes of mung bean (vigna radiata (L.) Wilczek). Bangladesh Journal of Botany. 42(1): 179-183.

[23] Nitu, N. J., Masum, M. M., Jannat, R., Sultana, S., and Bhuiyan, M. K. A. (2016). Application of chitosan and Trichoderma against soil-borne pathogens and their effect on yield of tomato (Solanum lycopersicum L.). International journal of Bioscience. 9 (1):10-24.

[24] O'Herlihy, E. A., Duffy, E. M., and Cassells, A. C. (2003). The effect of arbuscular mycorrhizal fungi and chitosan sprays on yield and late blight resistance in potato crops from plantlets. Folia Geobot. 38: 201-207.

[25] Photchanachai, S., Singkaew, J., and Thamthong, J. (2012). Effects of Chitosan Seed Treatment on Colletotrichum sp. and Seedling Growth of Chili cv. 'Jinda.' International Conference on Postharvest Pest and Disease Management in Exporting Horticultural Crops (PPDM). ISHS Acta Horticulture. p. 973.

[26] Poonpolgun, S., and Kumphai, S. (2007). Chilli Pepper Anthracnose in Thailand. Country Report. In: Oh, D. G., and Kim, K. T. editors. Abstract of the First International Sympogium on Chilli Anthracnose. National Horticulture Research Institute, Rural Development of Administration, Republic of Korea. p. 23.

[27] Pring, R. J., Nash, C., Zakaria, M., and Bailey, J. A. (1995). Infection process and host range of Colletotrichum capsici. Physiological and Molecular Plant Pathology. 46(2): 137-152.

[28] Rahman, M. M., Ali, M. A., Ahmad, M. U., and Dey, T. K. (2013). Effect of tuber-borne inoculum of Rhizoctonia solani on the development of stem canker and black scurf of potato. Bangladesh Journal of Plant Pathology. 29: 29-32.

[29] Rhouma, A., Ben-Daoud, H., Ghanmi, S., Ben- Salah, H., Romdhane, M., and Demak, M. (2009). Antimicrobial activities of leaf extracts of Pistacia and
Schinus species against some plant pathogenic fungi and bacteria. Journal of Plant Pathology. 91: 339-345.

[30] Rodriguez-Pedroso, A. T., Ramirez-Arrebato, M. A., Rivero-Gonzalez, D., Bosquez-Molina, E., BarreraNecha, L. L., and Bautista-Banos, S. (2009). Chemicalstructural properties and biological activity of chitosan on phytopathogenic microorganisms. Revista Chapingo Serie Horticultura. 15(3): 307-317.

[31] Romanazzi, G., and Feliziani, E. (2016). Use of chitosan to control postharvest decay of temperate fruit: effectiveness and mechanisms of action. In: BautistaBanos, S., Romanazzi, G., and Jimenez-Aparicio, A. editors. Chitosan in the Preservation of Agricultural Commodities Academic Press/Elsevier, USA. pp. 155177.

[32] Romanazzi, G., Gabler, F. M., and Smilanick, J. L. (2006). Preharvest chitosan and postharvest UV irradiation treatments suppress gray mold of table grapes. Plant Disease. 90: 445-450.

[33] Sharif, A. H. M., and Bhuiyan, K. A. (2005). Control of Colletotrichum capsici causing anthracnose of chilli (Capsicum annuum L.) by botanicals, chemicals and biocontrol agents. MS Thesis, Bangabandhu Sheikh Mujibur Rahman Agricultural University, Gazipur, Bangladesh.

[34] Simi, S. A. (2017). Application of Trichoderma fortified compost in controlling anthracnose disease of chilli (Capsicum frutescens L.). MS Thesis, Bangabandhu Sheikh Mujibur Rahman Agricultural University, Gazipur, Bangladesh.

[35] Sivakumar, D., Malick, B., Korsten, L., and Thompson, K. A. (2016). Integrated application of chitosan coating with different postharvest treatments on the control of postharvest decay and maintenance of overall fruit quality. In: Bautista-Banos, S., Romanazzi, G., and Jimenez-Aparicio, A. editors. Chitosan in the Preservation of Agricultural Commodities. Academic Press/Elsevier, USA. pp. 127-153.

[36] Sundar, A. R., Das, N. D., and Krishnaveni, D. (1995). In-vitro antagonism of Trichoderma spp. against two fungal pathogens of castor. Indian Journal of Plant Protection. 23(2): 152-155.

[37] Vasudevan, P., Reddy, M. S., Kavitha, S., Velusamy, P., Paul Raj, R. S. D., Priyadarisini, V. B. Bharathkumar. S., Kloepper, J. W., and Gnanamanickam, S. S. (2002). Role of biological preparations in enhancement of rice seedling growth and seed yield. Current Science. 83(9): 1140-1143.

[38] Walker, R., Morris, S., Brown, P., and Gracie, A. (2004). Evaluation of potential for Chitosan to enhance 
plant defense. Rural Industry Research Development

Corporation, Australia. pp. 55.

[39] Wilson, C. L., El Ghaouth, A., Chaluts, E., Droby, S., Stevens, C., Lu, J. L., Khan, V., and Arul, J. (1994).
Potential of induced resistance to control postharvest diseases of fruits and vegetables. Plant Disease. 78: 837-844.

Table.1. Pathogenicity of Colletotrichum capsici isolates on seedlings and fruits of chilli

\begin{tabular}{lcccc}
\hline \multirow{2}{*}{$\begin{array}{c}\text { Colletotrichum capsici } \\
\text { isolates }\end{array}$} & \multicolumn{3}{c}{ Seedlings } & Fruits \\
\cline { 2 - 3 } & $\begin{array}{c}\text { Pre-emergence } \\
\text { mortality }(\%)\end{array}$ & $\begin{array}{c}\text { Post-emergence } \\
\text { mortality }(\%)\end{array}$ & Total mortality (\%) & PDI \\
\cline { 2 - 4 } So & 17.00 & 46.00 & $63.00 \mathrm{a}$ & $83.33 \mathrm{a}$ \\
$\mathrm{Ba}$ & 9.66 & 18.66 & $28.32 \mathrm{c}$ & $56.25 \mathrm{c}$ \\
Mo & 8.30 & 34.70 & $43.00 \mathrm{~b}$ & $62.50 \mathrm{~b}$ \\
Untreated Control & 0.00 & 0.00 & $0.00 \mathrm{~d}$ & $0.00 \mathrm{~d}$ \\
\hline *Means within the same column having a common letter $(s)$ do not differ significantly $(P=0.05)$ by LSD.
\end{tabular}

Table.2. Effect of chitosan on mycelial growth of C. capsici

\begin{tabular}{lcc}
\hline \multicolumn{1}{c}{ Treatment } & $\begin{array}{c}\text { Average } \\
\text { mycelial growth after } 10 \\
\text { days }(\mathrm{mm})\end{array}$ & $\begin{array}{c}\text { mycelial growth inhibition over } \\
\text { control }\end{array}$ \\
\hline Control & $90.00 \mathrm{a}$ & - \\
$0.4 \%$ chitosan & $64.30 \mathrm{~b}$ & 28.56 \\
$0.6 \%$ chitosan & $36.70 \mathrm{c}$ & 59.22 \\
$0.8 \%$ chitosan & $11.00 \mathrm{~d}$ & 87.78 \\
$1 \%$ chitosan & $0.00 \mathrm{e}$ & 100.00 \\
$1.2 \%$ chitosan & $0.00 \mathrm{e}$ & 100.00 \\
\hline
\end{tabular}

*Means within the same column having a common letter $(s)$ do not differ significantly $(P=0.05)$ by LSD.

Table 3. Effect of chitosan and Bavistin on germination percentage and post-emergence seedling mortality

\begin{tabular}{|c|c|c|c|c|}
\hline Treatment & $\begin{array}{c}\% \\
\text { germination }\end{array}$ & $\begin{array}{c}\% \\
\text { increase over } \\
\text { control }\end{array}$ & $\begin{array}{c}\% \text { post-emergence } \\
\text { mortality }\end{array}$ & $\begin{array}{l}\% \text { reduction } \\
\text { over control }\end{array}$ \\
\hline Control & $73.00 \mathrm{c}$ & 29.50 & $13.28 \mathrm{~b}$ & 46.88 \\
\hline Seed treated with $C$. capsici & $56.37 \mathrm{~d}$ & - & $25.00 \mathrm{a}$ & - \\
\hline Seed treated with $C$. capsici $+0.6 \%$ chitosan & $82.00 \mathrm{~b}$ & 45.00 & $10.50 \mathrm{bc}$ & 58.00 \\
\hline Seed treated with $C$. capsici $+0.8 \%$ chitosan & $85.00 \mathrm{~b}$ & 45.47 & $9.47 \mathrm{bc}$ & 62.12 \\
\hline Seed treated with C. capsici $+1 \%$ chitosan & $92.10 \mathrm{a}$ & 63.38 & $7.67 \mathrm{~d}$ & 67.32 \\
\hline $\begin{array}{l}\text { Seed treated with } C \text {. capsici + Bavistin } \\
(0.1 \%) 50 \mathrm{WP}\end{array}$ & $81.57 \mathrm{~b}$ & 44.70 & $11.21 b c$ & 55.16 \\
\hline
\end{tabular}

*Means within the same column having a common letter(s) do not differ significantly $(P=0.05)$ by LSD.

Table.4: Effect of chitosan and Bavistin on growth parameters of chilli seedlings at 35 days after sowing (DAS)

\begin{tabular}{lcccccc}
\hline Treatments & $\begin{array}{c}\text { Shoot } \\
\text { length } \\
(\mathrm{cm})\end{array}$ & $\begin{array}{c}\text { Root } \\
\text { length } \\
(\mathrm{cm})\end{array}$ & $\begin{array}{c}\text { Fresh shoot } \\
\text { weight } \\
(\mathrm{g} / \mathrm{plant})\end{array}$ & $\begin{array}{c}\text { Fresh root } \\
\text { weight } \\
(\mathrm{g} / \mathrm{plant})\end{array}$ & $\begin{array}{c}\text { Dry shoot } \\
\text { weight } \\
(\mathrm{g} / \mathrm{plant})\end{array}$ & $\begin{array}{c}\text { Dry root } \\
\text { weight } \\
(\mathrm{g} / \mathrm{plant})\end{array}$ \\
\hline Control & $9.48 \mathrm{c}$ & $4.68 \mathrm{c}$ & $0.46 \mathrm{~cd}$ & $0.029 \mathrm{~b}$ & $0.063 \mathrm{c}$ & $0.0064 \mathrm{~b}$ \\
Seed treated with C. capsici & $10.12 \mathrm{c}$ & $5.13 \mathrm{c}$ & $0.53 \mathrm{bc}$ & $0.019 \mathrm{~b}$ & $0.055 \mathrm{~d}$ & $0.0020 \mathrm{c}$ \\
Seed treated with C. capsici + & $12.90 \mathrm{~b}$ & $6.59 \mathrm{~b}$ & $0.43 \mathrm{~d}$ & $0.025 \mathrm{~b}$ & $0.066 \mathrm{c}$ & $0.0067 \mathrm{~b}$
\end{tabular}


$0.6 \%$ chitosan

\begin{tabular}{|c|c|c|c|c|c|c|}
\hline $\begin{array}{l}\text { Seed treated with } C . \text { capsici }+ \\
0.8 \% \text { chitosan }\end{array}$ & $13.20 \mathrm{~b}$ & $7.14 \mathrm{ab}$ & $0.57 \mathrm{ab}$ & $0.032 \mathrm{ab}$ & $0.078 \mathrm{~b}$ & $0.0092 \mathrm{a}$ \\
\hline $\begin{array}{l}\text { Seed treated with } C . \text { capsici } \\
+1 \% \text { chitosan }\end{array}$ & $14.84 \mathrm{a}$ & $8.09 \mathrm{a}$ & $0.63 \mathrm{a}$ & $0.045 \mathrm{a}$ & $0.084 \mathrm{a}$ & $0.0098 \mathrm{a}$ \\
\hline $\begin{array}{l}\text { Seed treated with } C . \text { capsici }+ \\
\text { Bavistin }(0.1 \%) 50 \mathrm{WP}\end{array}$ & $12.85 \mathrm{~b}$ & $6.46 \mathrm{~b}$ & $0.44 \mathrm{~d}$ & $0.031 \mathrm{~b}$ & $0.067 \mathrm{c}$ & $0.0071 \mathrm{~b}$ \\
\hline
\end{tabular}

*Means within the same column having a common letter(s) do not differ significantly $(P=0.05)$ by LSD.

Table.5: Effect of chitosan and Bavistin on plant height and number of branches of chilli

\begin{tabular}{ccc|cc}
\hline \multirow{2}{*}{ Treatment } & \multicolumn{2}{c}{45 DAT } & \multicolumn{2}{c}{ 60 DAT } \\
\cline { 2 - 5 } & Plant height $(\mathrm{cm})$ & No. of branching & Plant height $(\mathrm{cm})$ & No. of branching \\
\hline $\mathrm{T}_{0}$ & $46.47 \mathrm{~h}$ & $13.58 \mathrm{~h}$ & $49.68 \mathrm{ef}$ & $16.16 \mathrm{~g}$ \\
$\mathrm{~T}_{1}$ & $45.52 \mathrm{i}$ & $11.30 \mathrm{i}$ & $47.93 \mathrm{f}$ & $13.18 \mathrm{~h}$ \\
$\mathrm{~T}_{2}$ & $47.30 \mathrm{~g}$ & $14.50 \mathrm{f}$ & $49.46 \mathrm{ef}$ & $17.40 \mathrm{e}$ \\
$\mathrm{T}_{3}$ & $48.70 \mathrm{f}$ & $14.57 \mathrm{f}$ & $50.83 \mathrm{e}$ & $17.65 \mathrm{e}$ \\
$\mathrm{T}_{4}$ & $53.78 \mathrm{~d}$ & $15.05 \mathrm{e}$ & $56.52 \mathrm{c}$ & $19.42 \mathrm{e}$ \\
$\mathrm{T}_{5}$ & $52.26 \mathrm{e}$ & $16.68 \mathrm{c}$ & $54.04 \mathrm{~d}$ & $18.41 \mathrm{~d}$ \\
$\mathrm{~T}_{6}$ & $53.93 \mathrm{c}$ & $15.64 \mathrm{~d}$ & $57.71 \mathrm{bc}$ & $19.79 \mathrm{~b}$ \\
$\mathrm{~T}_{7}$ & $57.54 \mathrm{~b}$ & $16.90 \mathrm{~b}$ & $59.49 \mathrm{ab}$ & $21.59 \mathrm{a}$ \\
$\mathrm{T}_{8}$ & $58.57 \mathrm{a}$ & $17.55 \mathrm{a}$ & $60.83 \mathrm{a}$ & $16.74 \mathrm{f}$ \\
$\mathrm{T}_{9}$ & $47.76 \mathrm{~g}$ & $13.76 \mathrm{~g}$ & $51.18 \mathrm{e}$ & \\
\hline
\end{tabular}

*Means within the same column having a common letter(s) do not differ significantly (P=0.05) by LSD.

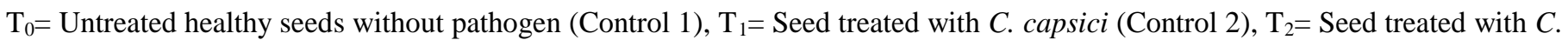
capsici $+0.6 \%$ chitosan, $\mathrm{T}_{3}=$ Seed treated with $C$. capsici $+0.8 \%$ chitosan, $\mathrm{T}_{4}=$ Seed treated with $C$. capsici $+1 \%$ chitosan, $\mathrm{T}_{5}=$ Seed treated with $C$. capsici + Foliar spray $(0.5 \%)$ of chitosan, $\mathrm{T}_{6}=\mathrm{T}_{2}+$ Foliar spray $(0.5 \%)$ of chitosan, $\mathrm{T}_{7}=\mathrm{T}_{3}+\mathrm{Foliar}$ spray $(0.5 \%)$ of chitosan, $\mathrm{T}_{8}=\mathrm{T}_{4}+$ Foliar spray $(0.5 \%)$ of chitosan, $\mathrm{T}_{9}=$ Seed treated with $C$. capsici $+0.1 \% \mathrm{Bavistin} 50 \mathrm{WP}$

Table 6. Effect of chitosan and Bavistin on disease incidence (DI) and percent disease index (PDI) of chilli

\begin{tabular}{|c|c|c|c|c|c|c|c|c|}
\hline \multirow[b]{2}{*}{ Treatment } & \multicolumn{4}{|c|}{$90 \mathrm{DAT}$} & \multicolumn{4}{|c|}{$120 \mathrm{DAT}$} \\
\hline & $\% \mathrm{DI}$ & $\begin{array}{c}\% \\
\text { Reduction } \\
\text { over } \mathrm{T}_{1}\end{array}$ & PDI & $\begin{array}{c}\% \\
\text { Reduction } \\
\text { over } \mathrm{T}_{1}\end{array}$ & $\% \mathrm{DI}$ & $\begin{array}{c}\% \\
\text { Reduction } \\
\text { over } \mathrm{T}_{1}\end{array}$ & PDI & $\begin{array}{c}\% \\
\text { Reduction } \\
\text { over } \mathrm{T}_{1}\end{array}$ \\
\hline $\mathrm{T}_{0}$ & $39.37 \mathrm{~b}$ & 39.12 & $1.30 \mathrm{~b}$ & 59.68 & $67.83 \mathrm{~b}$ & 24.90 & $2.6 \mathrm{~b}$ & 47.58 \\
\hline $\mathrm{T}_{1}$ & $64.67 \mathrm{a}$ & - & $3.34 \mathrm{a}$ & - & $90.33 \mathrm{a}$ & - & $4.96 \mathrm{a}$ & - \\
\hline $\mathrm{T}_{2}$ & $28.09 \mathrm{c}$ & 56.56 & $1.20 \mathrm{c}$ & 64.00 & $58.95 \mathrm{c}$ & 34.74 & $2.36 \mathrm{~cd}$ & 52.42 \\
\hline $\mathrm{T}_{3}$ & $27.07 \mathrm{c}$ & 58.14 & $1.13 \mathrm{c}$ & 66.07 & $48.67 \mathrm{~d}$ & 46.12 & $2.25 \mathrm{~d}$ & 54.64 \\
\hline $\mathrm{T}_{4}$ & $16.06 \mathrm{e}$ & 75.15 & $0.77 \mathrm{e}$ & 77.04 & $40.33 \mathrm{e}$ & 55.35 & $1.94 \mathrm{e}$ & 60.89 \\
\hline $\mathrm{T}_{5}$ & $16.20 \mathrm{e}$ & 74.95 & $0.79 \mathrm{e}$ & 76.45 & $34.22 \mathrm{fg}$ & 62.12 & $1.90 \mathrm{e}$ & 61.69 \\
\hline $\mathrm{T}_{6}$ & $15.13 \mathrm{ef}$ & 76.60 & $0.74 \mathrm{e}$ & 77.75 & $34.44 \mathrm{f}$ & 61.87 & $2.02 \mathrm{e}$ & 59.27 \\
\hline $\mathrm{T}_{7}$ & $13.33 \mathrm{f}$ & 79.60 & $0.71 \mathrm{e}$ & 78.74 & $31.49 \mathrm{~g}$ & 65.24 & $1.79 \mathrm{f}$ & 63.91 \\
\hline $\mathrm{T}_{8}$ & $10.08 \mathrm{~g}$ & 84.41 & $0.51 \mathrm{f}$ & 84.83 & $22.63 \mathrm{~h}$ & 74.95 & $1.29 \mathrm{~g}$ & 73.40 \\
\hline $\mathrm{T}_{9}$ & $20.37 \mathrm{~d}$ & 68.50 & $0.92 \mathrm{~d}$ & 72.46 & $43.13 \mathrm{e}$ & 52.25 & $2.24 \mathrm{~d}$ & 54.84 \\
\hline
\end{tabular}

* Means within the same column having a common letter $(s)$ do not differ significantly $(P=0.05)$ by LSD.

$\mathrm{T}_{0}=$ Untreated healthy seeds without pathogen (Control 1), $\mathrm{T}_{1}=$ Seed treated with $C$. capsici $\left(\right.$ Control 2), $\mathrm{T}_{2}=$ Seed treated with $C$. capsici $+0.6 \%$ chitosan, $\mathrm{T}_{3}=$ Seed treated with $C$. capsici $+0.8 \%$ chitosan, $\mathrm{T}_{4}=$ Seed treated with $C$. capsici $+1 \%$ chitosan, $\mathrm{T}_{5}=$ Seed treated with $C$. capsici + Foliar spray $(0.5 \%)$ of chitosan, $\mathrm{T}_{6}=\mathrm{T}_{2}+$ Foliar spray $(0.5 \%)$ of chitosan, $\mathrm{T}_{7}=\mathrm{T}_{3}+\mathrm{Foliar}$ spray $(0.5 \%)$ of chitosan, $\mathrm{T}_{8}=\mathrm{T}_{4}+$ Foliar spray $(0.5 \%)$ of chitosan, $\mathrm{T}_{9}=$ Seed treated with $C$. capsici $+0.1 \% \mathrm{Bavistin} 50 \mathrm{WP}$ 


\begin{tabular}{ccccc}
\multicolumn{5}{c}{ Table 7. Effect of chitosan and Bavistin on yield and thousand Seed weight (TSW) of chilli } \\
\hline Treatment & $\begin{array}{c}\text { Yield } \\
\text { \% increased yield } \\
\text { over } \mathrm{T}_{1}\end{array}$ & TSW $(\mathrm{g})$ & $\begin{array}{c}\text { \% increased TSW } \\
\text { over } \mathrm{T}_{1}\end{array}$ \\
\hline $\mathrm{T}_{0}$ & $3.62 \mathrm{i}$ & 26.57 & $4.28 \mathrm{~g}$ & 4.90 \\
$\mathrm{~T}_{1}$ & $2.86 \mathrm{j}$ & - & $4.08 \mathrm{~h}$ & - \\
$\mathrm{T}_{2}$ & $4.06 \mathrm{~g}$ & 41.91 & $4.33 \mathrm{~g}$ & 6.13 \\
$\mathrm{~T}_{3}$ & $4.36 \mathrm{f}$ & 52.45 & $4.49 \mathrm{f}$ & 10.05 \\
$\mathrm{~T}_{4}$ & $4.80 \mathrm{e}$ & 67.83 & $4.61 \mathrm{de}$ & 12.10 \\
$\mathrm{~T}_{5}$ & $5.60 \mathrm{~d}$ & 95.80 & $4.56 \mathrm{e}$ & 11.76 \\
$\mathrm{~T}_{6}$ & $5.98 \mathrm{c}$ & 109.09 & $4.75 \mathrm{c}$ & 16.42 \\
$\mathrm{~T}_{7}$ & $6.20 \mathrm{~b}$ & 116.78 & $4.88 \mathrm{~b}$ & 19.61 \\
$\mathrm{~T}_{8}$ & $7.03 \mathrm{a}$ & 145.80 & $5.04 \mathrm{a}$ & 23.52 \\
$\mathrm{~T}_{9}$ & $3.94 \mathrm{~h}$ & 37.76 & $4.67 \mathrm{~d}$ & 14.46 \\
\hline
\end{tabular}

*Means within the same column having a common letter(s) do not differ significantly $(P=0.05)$ by LSD .

$\mathrm{T}_{0}=$ Untreated healthy seeds without pathogen (Control 1), $\mathrm{T}_{1}=$ Seed treated with $C$. capsici $\left(\right.$ Control 2), $\mathrm{T}_{2}=$ Seed treated with $C$. capsici $+0.6 \%$ chitosan, $\mathrm{T}_{3}=$ Seed treated with $C$. capsici $+0.8 \%$ chitosan, $\mathrm{T}_{4}=$ Seed treated with $C$. capsici $+1 \%$ chitosan, $\mathrm{T}_{5}=$ Seed treated with $C$. capsici + Foliar spray $(0.5 \%)$ of chitosan, $\mathrm{T}_{6}=\mathrm{T}_{2}+$ Foliar spray $(0.5 \%)$ of chitosan, $\mathrm{T}_{7}=\mathrm{T}_{3}+$ Foliar spray $(0.5 \%)$ of chitosan, $\mathrm{T}_{8}=\mathrm{T}_{4}+$ Foliar spray $(0.5 \%)$ of chitosan, $\mathrm{T}_{9}=$ Seed treated with $C$. capsici $+0.1 \%$ Bavistin $50 \mathrm{WP}$

Table.8: Effect of chitosan and Bavistin on post-harvest disease incidence (DI) and percent disease index (PDI) of chilli at 135

\begin{tabular}{ccccc}
\hline Treatment & \% DI & \% reduction over $\mathrm{T}_{1}$ & PDI & \% reduction over $\mathrm{T}_{1}$ \\
\hline $\mathrm{T}_{0}$ & $24.83 \mathrm{~b}$ & 23.86 & $0.140 \mathrm{~b}$ & 15.15 \\
$\mathrm{~T}_{1}$ & $32.61 \mathrm{a}$ & - & $0.165 \mathrm{a}$ & - \\
$\mathrm{T}_{2}$ & $17.08 \mathrm{c}$ & 47.62 & $0.065 \mathrm{c}$ & 60.60 \\
$\mathrm{~T}_{3}$ & $15.62 \mathrm{~d}$ & 52.10 & $0.061 \mathrm{~d}$ & 63.03 \\
$\mathrm{~T}_{4}$ & $12.08 \mathrm{f}$ & 62.96 & $0.055 \mathrm{e}$ & 66.67 \\
$\mathrm{~T}_{5}$ & $14.54 \mathrm{e}$ & 55.41 & $0.057 \mathrm{e}$ & 65.45 \\
$\mathrm{~T}_{6}$ & $12.78 \mathrm{f}$ & 60.81 & $0.045 \mathrm{f}$ & 72.73 \\
$\mathrm{~T}_{7}$ & $12.33 \mathrm{f}$ & 62.19 & $0.042 \mathrm{f}$ & 74.55 \\
$\mathrm{~T}_{8}$ & $8.58 \mathrm{~g}$ & 73.69 & $0.026 \mathrm{~g}$ & 84.24 \\
$\mathrm{~T}_{9}$ & $14.89 \mathrm{de}$ & 54.34 & $0.057 \mathrm{e}$ & 65.45 \\
\hline$*$ Means within the same column having a common letter $(s)$ do not differ significantly $(P=0.05)$ by LSD.
\end{tabular}

$\mathrm{T}_{0}=$ Untreated healthy seeds without pathogen (Control 1), $\mathrm{T}_{1}=$ Seed treated with $C$. capsici $\left(\right.$ Control 2), $\mathrm{T}_{2}=$ Seed treated with $C$. capsici $+0.6 \%$ chitosan, $\mathrm{T}_{3}=$ Seed treated with $C$. capsici $+0.8 \%$ chitosan, $\mathrm{T}_{4}=$ Seed treated with $C$. capsici $+1 \%$ chitosan, $\mathrm{T}_{5}=$ Seed treated with $C$. capsici + Foliar spray $(0.5 \%)$ of chitosan, $\mathrm{T}_{6}=\mathrm{T}_{2}+$ Foliar spray $(0.5 \%)$ of chitosan, $\mathrm{T}_{7}=\mathrm{T}_{3}+$ Foliar spray $(0.5 \%)$ of chitosan, $\mathrm{T}_{8}=\mathrm{T}_{4}+$ Foliar spray $(0.5 \%)$ of chitosan, $\mathrm{T}_{9}=$ Seed treated with $C$. capsici $+0.1 \%$ Bavistin $50 \mathrm{WP}$ 


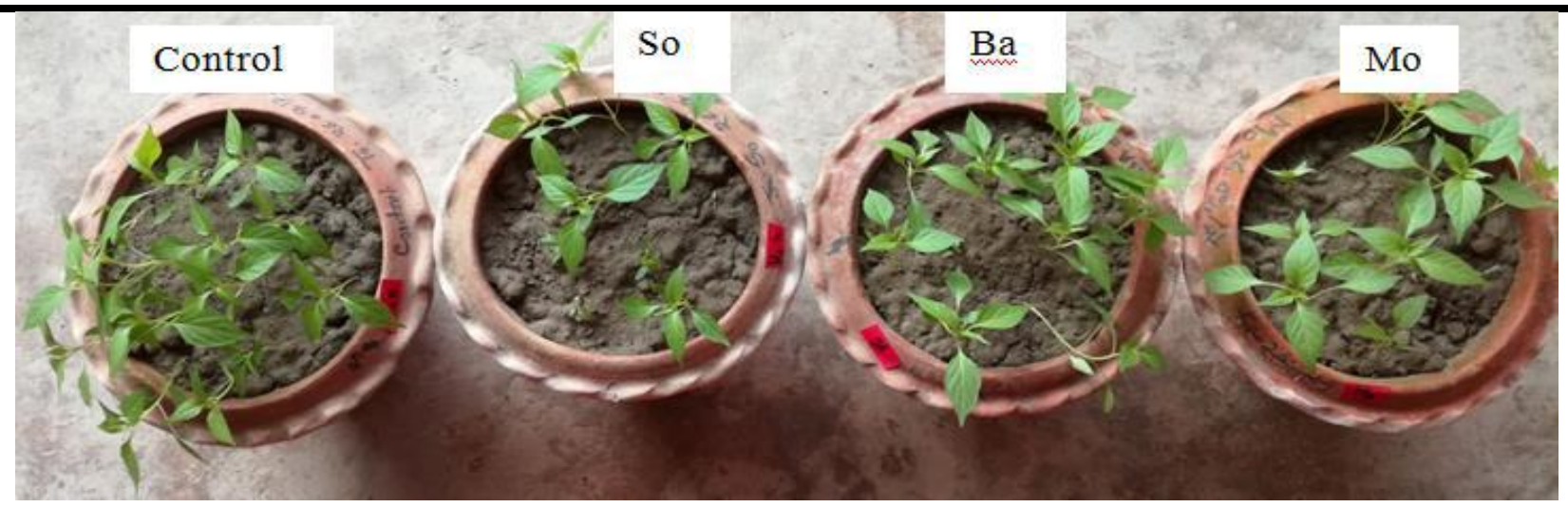

Fig. 1: Pathogenicity test of C. capsici isolates against chilli seedling

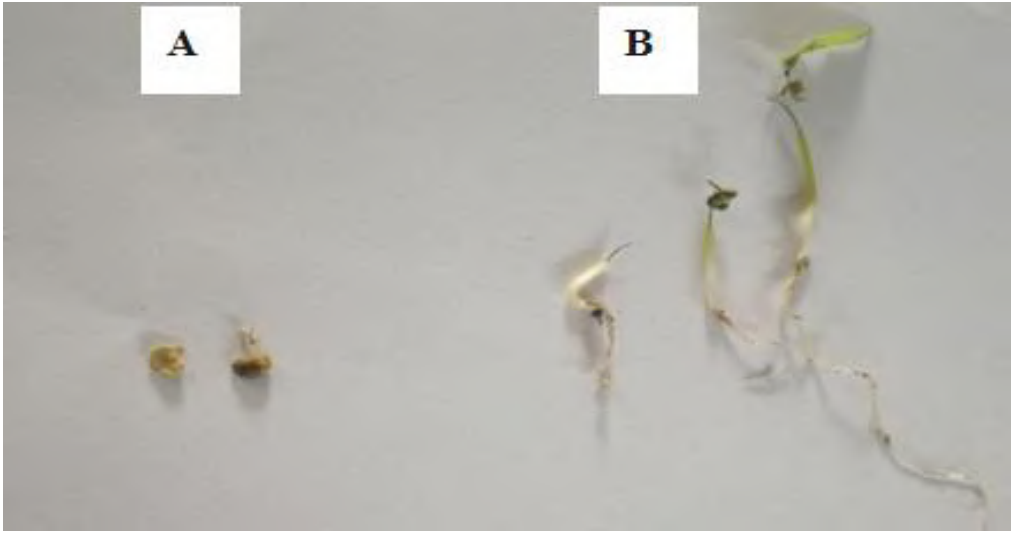

Fig. 2: Pre-emergence (A) and post-emergence $(B)$ seedling mortality

\section{Control}

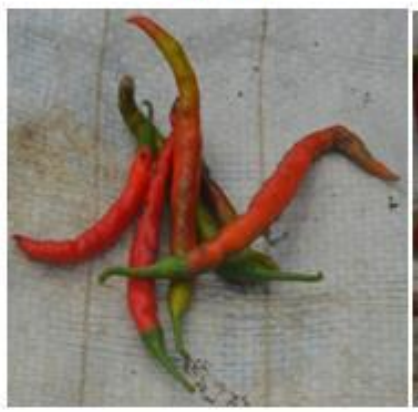

So

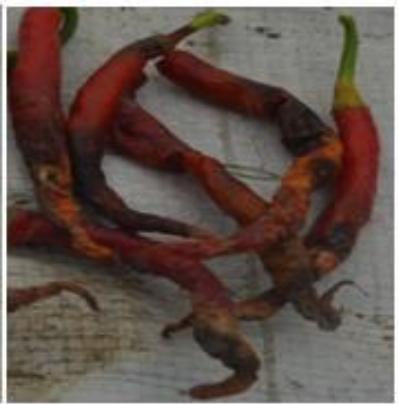

$\mathrm{Ba}$

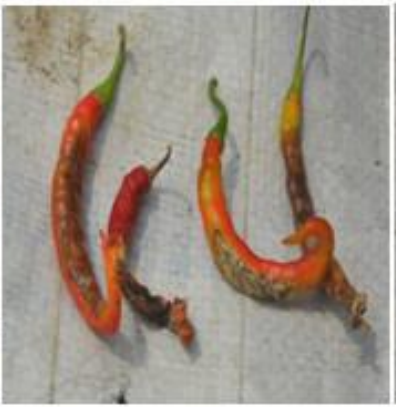

Mo

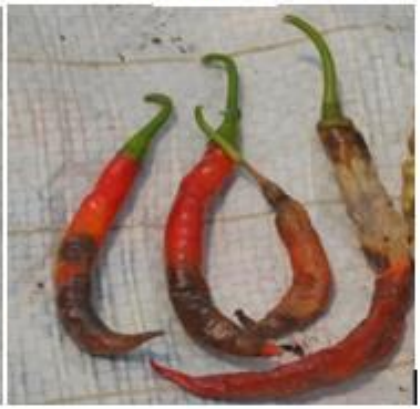

Fig. 3: Pathogenicity test of $C$. capsici isolates on chilli fruit
Control
$0.6 \%$ chitosan
$0.8 \%$ chitosan
$1 \%$ chitosan

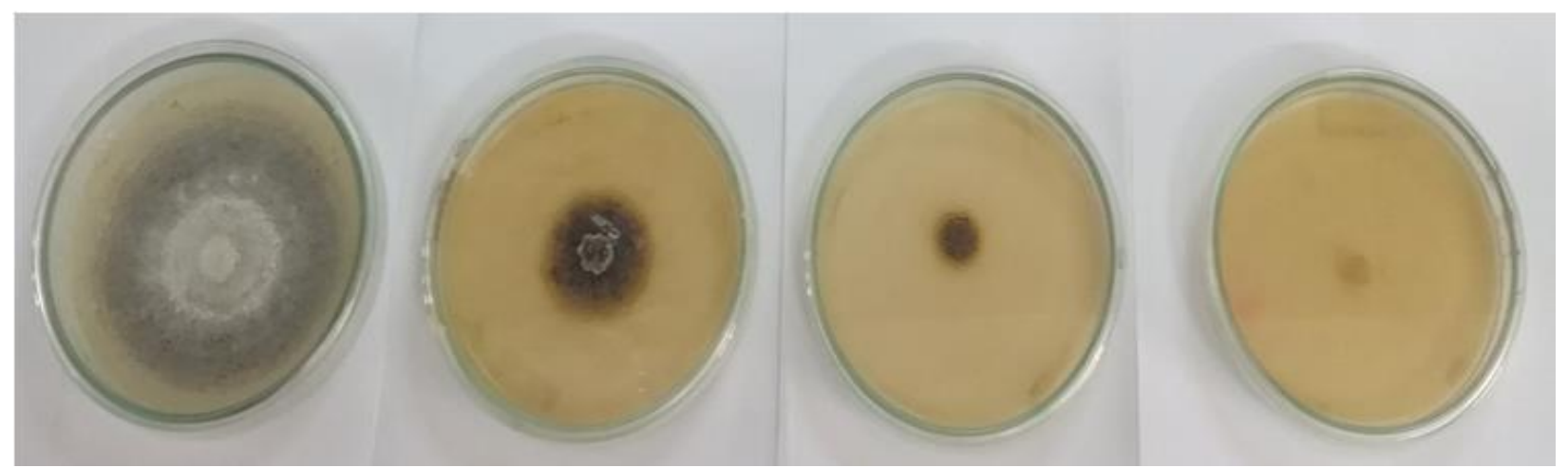

Fig. 4. Mycelial growth inhibition of C. capsici by chitosan on PDA 